\title{
A Simulation Model of Production, Seasonal Changes in Biomass and Distribution of Eelgrass (Zostera marina) in Lake Grevelingen
}

\author{
J. H. G. Verhagen ${ }^{1}$ and P. H. Nienhuis ${ }^{2}$ \\ ${ }^{1}$ Delft Hydraulics Laboratory, P. O. Box 177, 2600 MH Delft, The Netherlands \\ 2 Delta Institute for Hydrobiological Research, Vierstraat 28, 4401 EA Yerseke, The Netherlands
}

\begin{abstract}
Based on data from Lake Grevelingen, The Netherlands, a simulation model has been described which refers to growth rates per unit eelgrass biomass, obtained with the leaf-marking technique, and to above-ground biomass and shoot-density changes per unit area. Space limitation depending on density of the above-ground biomass and growth limitation due to shortage in belowground biomass have been introduced. Seasonal changes in eelgrass production, both above and below ground, have been simulated as functions of the external forcing variables light, water temperature, wind-generated water movements and internal control variables due to ageing of the plant material. The vertical distribution of eelgrass can be partly explained from modelling results on space, light and below-ground biomass limitations. Together with additional data - not used in the model - on seed production and growth of eelgrass shoots from seeds, vertical and horizontal distributions can be explained satisfactorily.
\end{abstract}

\section{INTRODUCTION}

The model presented in this paper has been based on studies carried out in Lake Grevelingen, SWNetherlands - a former estuary and since 1971 a brackish water lake, connected with the North Sea by sluices. The lake has a surface area of $108 \mathrm{~km}^{2}$; about $60 \%$ of its area is shallower than $5 \mathrm{~m}$. In the tideless lake, chlorinity of the water varied between 12.5 and $14 \%$ in 1976 .

The submerged macrophyte eelgrass Zostera marina increased enormously after closure of the dam in 1971 (1200 ha in 1968, 4400 ha in 1978). Soon after 1971 , eelgrass production within the beds reached approximately 100 to $150 \mathrm{~g} \mathrm{C} \mathrm{m}^{-2} \mathrm{Yr}^{-1}$. Eelgrass production for the entire lake increased from 5 to $50 \mathrm{~g} \mathrm{C} \mathrm{m}^{-2} \mathrm{yr}^{-1}$ within 10 yr (Nienhuis, 1980).

In literature the number of mathematical models for marine macrophytes is scarce (Jansson, 1975; Belyeav et al. 1977; Short, 1980). This is particularly true for eelgrass, although eelgrass ecosystems are among the most productive marine systems in the world, mathematical simulation of their dynamics has hardly ever been attempted (Short, 1980).

This paper presents a mathematical model for growth, decomposition, and distribution of eelgrass in relation to external forcing functions in Lake Grevelingen, applicable as a predictive tool for lake management. A detailed report on the model has been presented by Verhagen (1981). The model was developed as part of a large-scale aquatic modelling effort in Lake Grevelingen.

\section{MATERIAL AND METHODS}

\section{Structure of the Model}

The model is based on data published by Nienhuis and De Bree $(1977,1980)$ and additional data provided by the second author. Growth and decomposition of eelgrass in 1976 have been formulated as functions of a number of forcing variables, such as light, water temperature and wind generated water movements. On account of the permanently high levels of nutrients in the interstitial waters of the sediment (Holland and Al, 1980 ; Kelderman, 1981) it is supposed that eelgrass growth is not limited by nutrient availability in Lake Grevelingen.

To incorporate the effect of ageing, the shoots (i. e. 


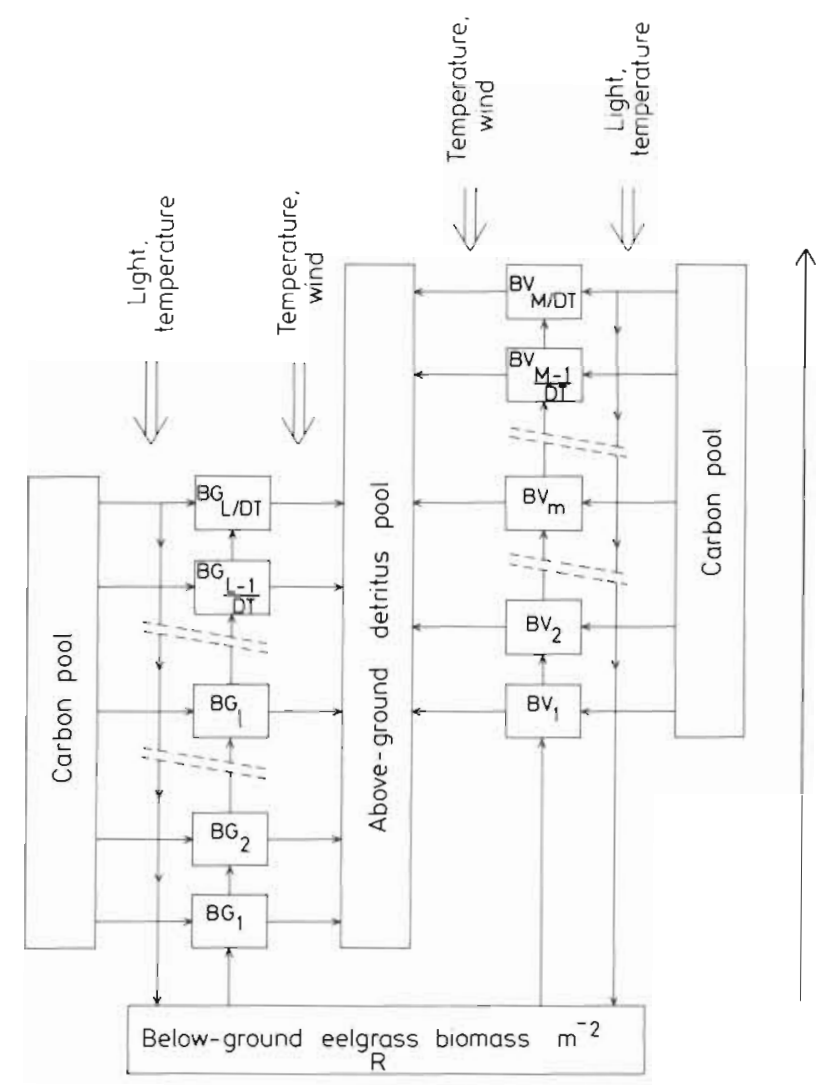

parts of eelgrass plants attached to a rhizome) in the model are divided into age classes. Consequently, eelgrass growth at a given moment not only depends on the instantaneous forcing functions, but also on the environmental conditions prevailing during the preceding period.

The following limiting factors in the production of new above-ground shoots have been introduced: (a) a space limitation, depending on the density of the above-ground biomass; (b) a growth limitation due to shortage in below-ground biomass.

A distinction has been made between 2 growth forms of shoots, viz. an early growth form starting vegetatively and resulting in generative branching and flowering (generative shoot), and a late summer growth form (an unbranched vegetative shoot). The 2 growth forms are subdivided into age classes, L/DT age classes for the generative shoots and M/DT for the vegetative shoots, where DT is the simulation timestep and L and $M$ are maximum ages.

Growth and decomposition of each growth form have been formulated as first order processes, i. e. the rate of change in biomass is proportional to the biomass present. Growth rate per unit biomass, the relative growth rate, has been described as a function of the external forcing variables light and water temperature and as a function of internal control variables due to ageing. The relative decomposition - or loss rate of eelgrass
Fig. 1. Outline of model structure for the eelgrass population in Lake Grevelingen. Open arrows: action of forcing functions. Right-hand arrow: time axis along which pools BG and BV are filled successively from inorganic carbon pool and from Pool $R$, and subsequently emptied in the detritus pool. Above-ground biomass $\mathrm{B}=$

$$
\sum_{l=1}^{L / D T} B G_{1}+\sum_{m=1}^{M / D T} B V_{m}
$$

biomass has been described as a function of water temperature and water movements due to windinduced waves and currents and is also dependent on age. An outline of the model structure is given in Fig. 1.

\section{Growth and Decomposition of One Eelgrass Shoot}

Table 1 shows the rate of change in biomass of 1 eelgrass shoot. Concomitant with increasing plant age, the relative growth rate is assumed to decrease and the relative loss rate to increase. Maximum age of the generative growth form has been obtained from a calibration with available data on above-ground eelgrass biomass and shoot density; it appeared to be approximately $70 \mathrm{~d}$. Maximum age of the vegetative growth form has been obtained in the same manner; it appeared to be about $40 \mathrm{~d}$. Loss rate due to windinduced waves and currents is supposed to be strongly dependent on water depth, reaching maximum values in shallow water $(0$ to $1 \mathrm{~m}$ ) where wave height can be of the same order as water depth. It is assumed that light intensity at the bottom determines eelgrass growth; this is valid only if the mean plant length is small compared to water depth. The reason for this approximation is to avoid the difficulty of modelling plant length at various water depths. Data on insolation, extinction coefficients, water temperature and 
Table 1. Rate of change in biomass of 1 eelgrass shoot. (1) Values based on direct measurements; (2) values based on a combination of direct measurements, literature values and assumptions; (3) values based on assumptions with little validation, but considered reasonable estimates

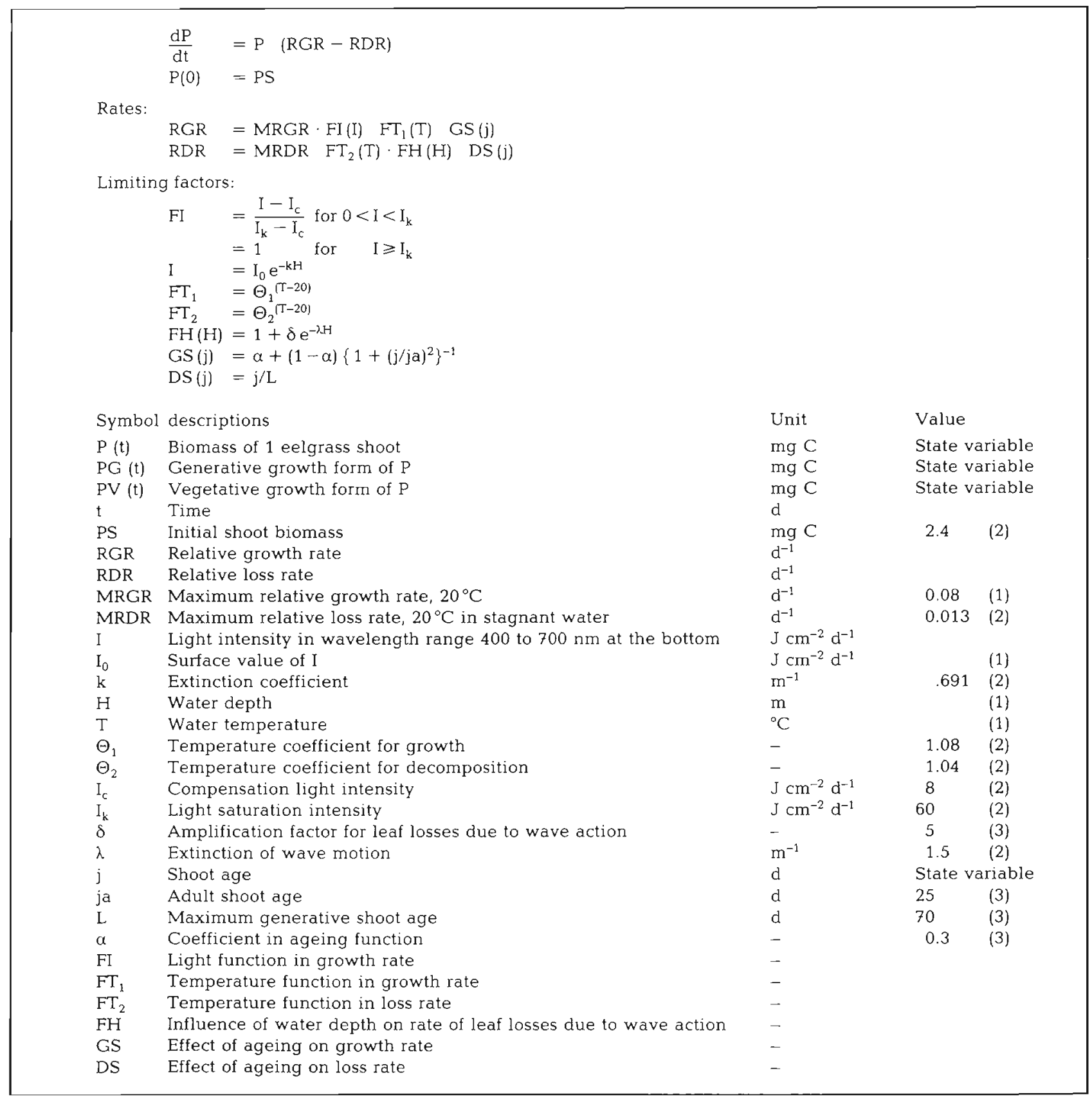

water movements were available from the Delta Institute for Hydrobiological Research, and the Delta Department, Environmental Research Divison of the Ministry of Transport and Public Works and from Pellikaan (1980).

The choice of the specific functions and parameters, as shown in Table 1, has been changed several times during the calibration process. The model appeared to be less sensitive to these data as compared to some of those mentioned in Table 2.

\section{Production of New Shoots and Loss of Shoots}

Table 2 shows the increase in numbers of new shoots per $\mathrm{m}^{2}$, related to the limiting factors considered. The effect of space limitation will be more severe with increasing standing stock, and above a given value of the above-ground biomass the production of new shoots will cease.

It is assumed that the emergence of new shoots results from a translocation of carbon from the 
Table 2. Increase in numbers of new eelgrass shoots per $\mathrm{m}^{2}$ For explanation consult Table 1 (1), (2) and (3)

Rates:

$$
\begin{aligned}
& \mathrm{DNDTG}=\mathrm{DNDTM} \cdot \mathrm{FI}(\mathrm{I}) \quad \mathrm{FT}_{3}(\mathrm{~T}) \cdot \mathrm{FB}(\mathrm{B}) \quad \mathrm{FR}(\mathrm{R}) \quad \text { for } \mathrm{t} \leqslant \mathrm{DDAY} \\
& \mathrm{DNDTV}=\mathrm{A} \cdot \mathrm{DNDTG}(\mathrm{t}-\mathrm{L}) \cdot \mathrm{FL}(\mathrm{I}) \cdot \mathrm{FT}_{3}(\mathrm{~T}) \mathrm{FB}(\mathrm{B}) \quad \mathrm{FR}(\mathrm{R}) \text { for } t>\mathrm{DDAY}
\end{aligned}
$$

Limiting factors:

$$
\begin{array}{rlrl}
\mathrm{FI} & =\text { as in Table } 1 & \\
\mathrm{FT}_{3} & =\frac{T-\mathrm{T}_{0}}{\mathrm{kT}+\mathrm{T}-\mathrm{T}_{0}} & \text { for } \mathrm{T} \geqslant \mathrm{T}_{0} \\
& =0 & \text { for } \mathrm{T}<\mathrm{T}_{0} \\
\mathrm{FB} & =1-\left(\frac{\mathrm{B}}{\sigma}\right)^{2} & & \text { for } \mathrm{B} \leqslant \sigma \\
& =0 & \text { for } \mathrm{B}>\sigma \\
\mathrm{FR} & =\frac{\mathrm{R}}{\mathrm{R}+\varepsilon} & & \text { for } \mathrm{R} \geqslant 0
\end{array}
$$

Symbol descriptions

DNDTG Production of new shoots of the generative growth form $\mathrm{m}^{-2}, \mathrm{~d}^{-1}$

$\begin{array}{ll}\begin{array}{ll}\text { Unit } \\ \text { number }\end{array} & \text { Value } \\ \frac{m^{2} \mathrm{~d}}{\text { number }} & \text { Rate } \\ \mathrm{m}^{2} \mathrm{~d} & \text { Rate } \\ \mathrm{mg} \mathrm{C} \mathrm{m^{-2 }} & \text { State variable } \\ \mathrm{mg} \mathrm{C} \mathrm{m^{-2 }} & \text { State variable }\end{array}$

DNDTV Production of new shoots of the vegetative growth form $\mathrm{m}^{-2}, \mathrm{~d}^{-1}$

$$
\begin{array}{ll}
\text { B } & \text { Above-ground biomass } \mathrm{m}^{-2} \\
\mathrm{R} & \text { Below-ground biomass } \mathrm{m}^{-2}
\end{array}
$$

Parameter values

DNDTM Maximum production of new shoots $\mathrm{m}^{-2}, \mathrm{~d}^{-1}$

\begin{tabular}{|c|c|}
\hline$\frac{\text { number }}{\mathrm{m}^{2} \mathrm{~d}}$ & 150 \\
\hline${ }^{\circ} \mathrm{C}$ & 9 \\
\hline${ }^{\circ} \mathrm{C}$ & 3 \\
\hline $\mathrm{mg} \mathrm{C} \mathrm{m} \mathrm{m}^{-2}$ & $42.10^{3}$ \\
\hline $\mathrm{mg} \mathrm{C} \mathrm{m} \mathrm{m}^{-2}$ & $0.47 \cdot 10^{3}$ \\
\hline- & 1.4 \\
\hline d & 215 \\
\hline - & \\
\hline- & \\
\hline - & \\
\hline
\end{tabular}

$\mathrm{T}_{0} \quad$ Temperature below which no shoots are produced

kT Michaelis constant for temperature

$\sigma \quad$ Above-ground biomass above which no new shoots are produced

$\varepsilon \quad$ Michaelis constant for rhizome biomass

$\begin{array}{ll}\text { A } & \text { Multiplier } \\ \text { DDAY } & \text { Time switch from generative to vegetative shoot production }\end{array}$

$\mathrm{FI}_{3} \quad$ Temperature function in the production of new shoots

FB Reduction factor in the production of new shoots due to space limitation

FR Reduction factor in the production of new shoots due to rhizome limitation -

Table 3. Rate of change in below-ground eelgrass biomass. For explanation consult Table 1, (2) and (3)

$$
\begin{aligned}
& \frac{\mathrm{dR}}{\mathrm{dt}}=\mathrm{K} 1 \cdot \mathrm{PR}-\mathrm{PS}(\mathrm{DNDTG}+\mathrm{DNDTV})-\mathrm{K} 2 \cdot \mathrm{PLOSS} \\
& \operatorname{PLOSS}=\frac{1}{2} \operatorname{DNDTG}(t-L)+\frac{1}{2} \operatorname{DNDTV}(t-M)+\frac{1}{2 L} \int_{0}^{L} \operatorname{DNDTG}(t-\tau) d \tau+ \\
& +\frac{1}{2 M} \int_{0}^{M} \operatorname{DNDTV}(t-\tau) d \tau \\
& P R=\int_{0}^{L} \operatorname{DNDTG}(t-\tau)\left(1-\frac{1}{2} \frac{\tau}{L}\right) \quad P G(\tau, t) \quad R G R(t, \tau) \cdot d \tau+ \\
& +\int_{0}^{M} \operatorname{DNDTV}(t-\tau)\left(1-\frac{1}{2} \frac{\tau}{M}\right) \cdot \operatorname{PV}(\tau, t) \quad R G R(t, \tau) \cdot d \tau
\end{aligned}
$$

Symbol descriptions

K1 Proportionality constant

K2 Below-ground biomass of 1 uprooted shoot

L. Maximum age of generative shoot

$M \quad$ Maximum age of vegetative shoot

PLOSS Loss rate of shoots

$\begin{array}{lll}\text { Unit } & \text { Value } \\ - & 0.19 & (2) \\ \text { mg C } & 2.0 & (3) \\ \mathrm{d} & 70 & (3) \\ \mathrm{d} & 40 & (3) \\ \frac{\text { number }}{\mathrm{m}^{2} \mathrm{~d}} & \text { Rate } & \\ \frac{\mathrm{mg} \mathrm{C}}{\mathrm{m}^{2} \mathrm{~d}} & \text { Rate }\end{array}$

PR Above-ground production 
rhizomes. On the other hand, root and rhizome production are fed by a transfer of carbon from the aboveground biomass. A constant portion $(17 \%$ on dry weight basis; cf. McRoy, 1974) of the carbon fixed by the leaves is supposed to be translocated to the roots and rhizomes. As a consequence of the allocation of organic carbon from below-to above-ground eelgrass parts, the below-ground biomass pool may be heavily depleted in autumn, causing a decreased production of new shoots the following year.

In addition to the limiting factors mentioned, which are basic to the behaviour of the model, light and temperature as limiting factors have been introduced. The start of shoot production in spring is related to water temperature.

A further important assumption is that the production of new vegetative shoots in the second half of the growing season is related to the production of generative shoots in the first half. Both growth forms belong to the same annual eelgrass plant. After an initial generative growth period the same plant develops a vegetative shoot while the generative shoot dies. As a consequence, the production of new vegetative shoots is supposed to be proportional to the number of generative shoots reaching maximum age. The introduction of 2 growth forms implies an arbitrary day on which the generative growth form is replaced by the vegetative one. This day is called DDAY $=215$, i. e. 2 August 1976.

Fortunately, the model is rather unsensitive to the choice of DDAY, due to the fact that in summer the biomass maximum is reached, implying that the space limitation factor works in the model at a maximum, resulting in the production of hardly any new shoots. Again, development of biomass and shoot density in the course of the year are largely dominated by the limiting factors introduced in the production of new above-ground shoots. The model is, therefore, most sensitive to the choice of the limiting factors FB and FR. These specific functions have not been measured but have been assumed with little validation (Table 2 ).

We assume that shoots reaching their maximum age are transported out of the eelgrass bed; however, this is only partly true. We finally assume that the number of shoots originated at a given date decreases linearly with age, to an extent that at maximum age only half of the initial number is left (Table 3). The model appeared not to be very sensitive for changes in loss rate.

\section{Underground Biomass}

Rates of changes in underground biomass are listed in Table 3. The underground biomass consists of creeping rhizomes and roots. On account of the assumed translocations of organic carbon, the increase in underground biomass has been taken to be proportional with the above-ground production. The proportionality coefficient $\left(\mathrm{K}_{1}\right)$, obtained by calibration, turned out to be 0.19 ; this is comparable with data of McRoy (1974).

The decrease in below-ground biomass is caused by (a) transfer of energy from rhizomes to above-ground shoot production - assuming that this transfer equals the number of shoots produced per unit time multiplied by the biomass of 1 shoot; (b) uprooting of complete eelgrass plants, which is proportional to the loss rate of shoots. The below-ground biomass of 1 uprooted shoot $\left(\mathrm{K}_{2}\right)$ proved to be $2 \mathrm{mgC}$.

\section{Above-Ground Biomass $\mathbf{m}^{-2}$}

The above-ground biomass $\mathrm{m}^{-2}$ is the sum of the biomasses of all age classes of the growth forms. The biomass per age class is obtained by multiplying shoot density and single-shoot biomass per age class (Table 4).

Table 4. Equation of above-ground eelgrass biomass $\mathrm{m}^{-2}$

$$
\begin{aligned}
B & =\int_{0}^{L} \operatorname{DNDTG}(t-\tau)\left(1-\frac{1}{2} \frac{\tau}{L}\right) \cdot \operatorname{PG}(t, \tau) d \tau+ \\
& +\int_{0}^{M} \operatorname{DNDTV}(t-\tau)\left(1-\frac{1}{2} \frac{\tau}{M}\right) \cdot \operatorname{PV}(t, \tau) \cdot d \tau
\end{aligned}
$$

The period of 1 age class in the simulation model has been chosen to equal the timestep in the numerical solution of the differential equation; it is DT $=0.5 \mathrm{~d}$. This leads to a rather large number of age classes $([\mathrm{L}+\mathrm{M}] / \mathrm{DT}=220)$, but the accuracy of the calculation is improved. Later, model results were composed of biologically more meaningful age classes of $10 \mathrm{~d}$ each. Together with the differential equation for the underground biomass the eelgrass model consists, therefore, of 221 non-linear, coupled first-order ordinary differential equations for the 221 state variables; these were solved on a DEC-10 computer at the Wageningen Hydraulic Laboratory.

\section{Calibration of the Model}

The model was calibrated on data of seasonal 1976 changes in above-ground eelgrass biomass and shoot density at the water depth of the permanent sample plot $(0.75 \mathrm{~m})$. During calibration - a trial and error procedure with judgement by eye as matching crite- 


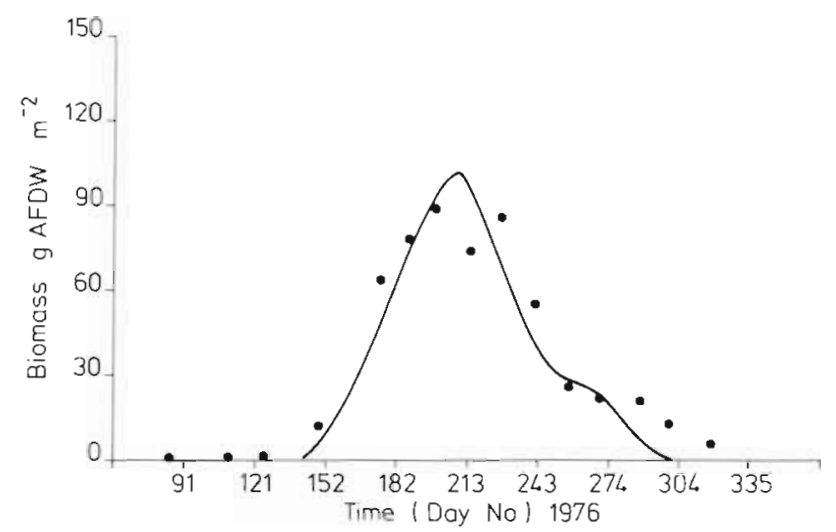

Fig. 2. Above-ground eelgrass biomass in the $10 \times 10 \mathrm{~m}^{2}$ permanent quadrat in Lake Grevelingen; water depth, $0.75 \mathrm{~m}$. Solid line: model calibration; - measured data in $\mathrm{g}$ ash-free dry weight (AFDW) $\mathrm{m}^{-2}$

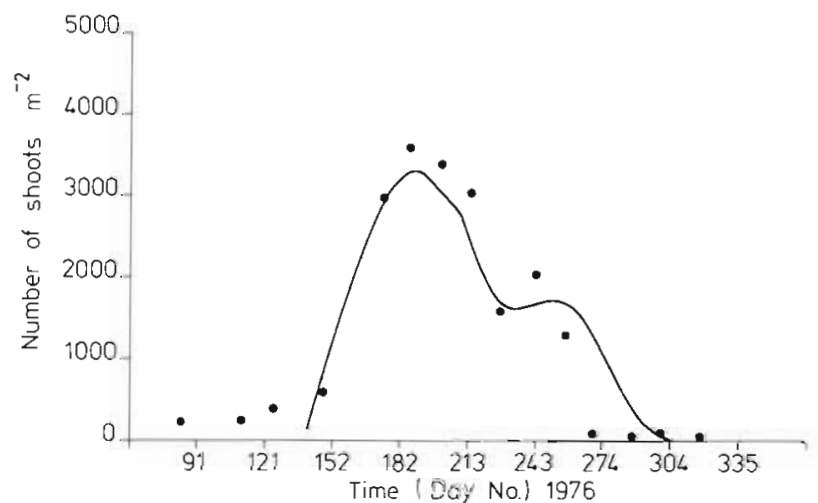

Fig. 3. Shoot density of eelgrass in the $10 \times 10 \mathrm{~m}^{2}$ permanent quadrat in Lake Grevelingen; water depth, $0.75 \mathrm{~m}$. Solid line: model calibration; $\bullet$ measured data

rion - the parameters in Tables 1 to 3 denoted by the index 3 and certain functions (notably FB and FR) have been changed within certain limits. Results of the calibration are shown in Figs. 2 and 3 . The discrepancy between calibrated model results and actual data at the end of the growing season is probably due to a reduced reliability of measured data, since the mean biomass of an eelgrass plant, which can be obtained by dividing the measured standing stock values by the measured shoot density, is unrealistically high. This means that either the measured shoot densities are too low and/or the measured standing stock values are too high in that period.

A second discrepancy concerns the shape of the tip of the biomass curve: the measured curve is less sharp than the calculated one. Perhaps this is due to the fact that plants are transported less spontaneously out of the eelgrass beds than has been assumed in the model.

\section{RESULTS AND DISCUSSION}

Available data, not used for the calibration, have been applied for model verification. The data com- prise: seasonal changes in above-ground eelgrass production and in underground biomass and production at $0.75 \mathrm{~m}$ water depth; the distribution of the above-and below-ground biomass of eelgrass from 0.5 to $4 \mathrm{~m}$ water depth (Nienhuis and De Bree, 1977, 1980).

Nienhuis and De Bree (1980) obtained production values with the leafmarking technique, a generally accepted and recommended method (McRoy and McMillian, 1977; Zieman and Wetzel, 1980) for measuring eelgrass net production. They calculated a net above ground production of $649 \mathrm{~g}$ ash-free dry weight (AFDW) $\mathrm{m}^{-2} \mathrm{yr}^{-1}$, in which biomass increment per eelgrass leaf bundle per day was multiplied by the number of leaf bundles per $\mathrm{m}^{2}$, as recommended by Sand-Jensen (1975). This calculation (Method I) is open for serious over- or underestimates of the production proper. The small sample of marked leaf bundles (10) from a population of 2000 to 12000 bundles of leaves $\mathrm{m}^{-2}$ in summer has to be taken at random. This requirement appeared difficult to meet, especially during summer, when a large number of short leaves develop on flowering shoots. Closer inspection of the data (Nienhuis and De Bree, 1980) revealed that the leaf bundles chosen appeared to be too heavy during the summer months, compared to the mean weight of the leaf bundles. This led to an overestimation of net above-ground production.

Net above-ground eelgrass production may also be expressed as biomass increment per leaf bundle per day, divided by the biomass of the leaf bundle, averaged over the sample of marked leaf bundles, and multiplied by the average biomass per $\mathrm{m}^{2}$ (relative net production). In this way net production reached a level of $274 \mathrm{~g}$ AFDW $\mathrm{m}^{-2} \mathrm{yr}^{-1}$. This calculation method, expressing a relative growth rate, is less sensitive to the choice of the marked leaf bundles and is therefore to be preferred. This means that the eelgrass production data for Lake Grevelingen, as given by Nienhuis

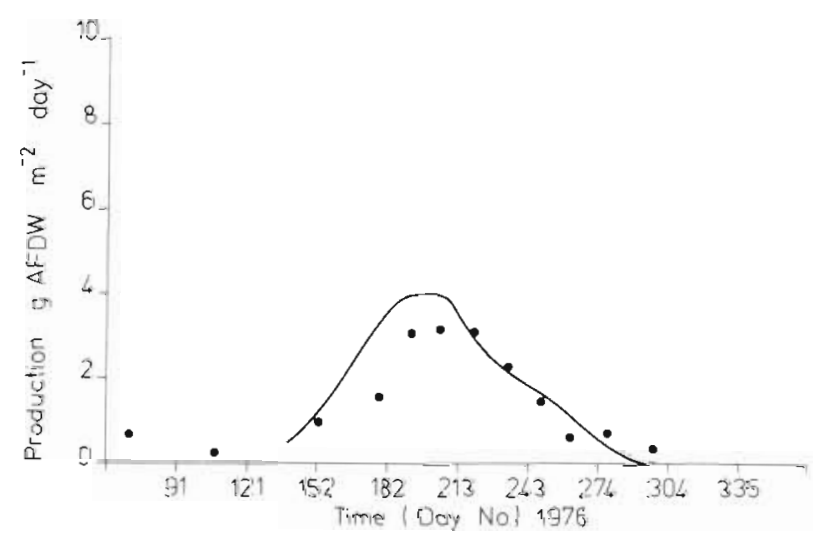

Fig. 4. Net production of above-ground eelgrass in the $10 \times 10 \mathrm{~m}^{2}$ permanent quadrat in Lake Grevelingen; water depth, $0.75 \mathrm{~m}$. Solid line: model simulation; $\bullet$ measured data according to leaf-marking technique, calculation Method II 


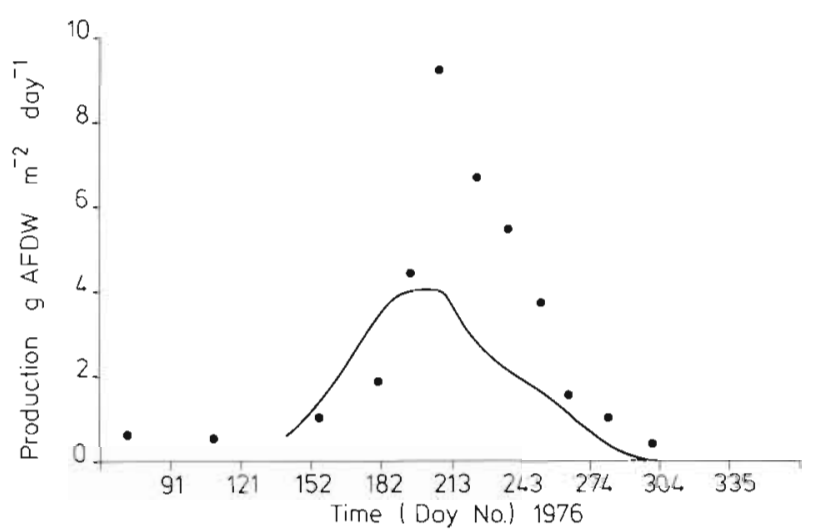

Fig. 5. Net production of above-ground eelgrass (stems and inflorescences excluded) in the $10 \times 10 \mathrm{~m}^{2}$ permanent quadrat in Lake Grevelingen; water depth, $0.75 \mathrm{~m}$. Solid line: model simulation; - measured data according to the leafmarking technique, calculation Method I

and De Bree (1980), have to be divided by a factor of 2.4 .

When the original data of the 1976 measurements (Nienhuis and De Bree, 1980) are calculated according to Method II, an estimate of level and seasonal changes in production is obtained which is fairly well comparable with the model results (Fig. 4). This is not the case when Method I is used (Fig. 5), indicating again the superiority of calculation Method II if applying the leaf-marking technique.

Biomass and production rates of roots and rhizomes, as measured in the field (Nienhuis and De Bree, 1980) and as calculated from the model, are shown in Figs. 6 and 7 . Evidently, the model calculation of the underground production in the second half of the growing season is too low. The model introduces a constant portion of the above-ground production being transferred to the below ground biomass, derived from data given by McRoy (1974). This assumption seems to be incorrect. Obviously, a larger proportion of downward energy transport has to be accepted for the vegetative shoot as compared to the generative shoot. The unrealistically strong dip in the calculated below ground biomass curve (Fig. 6) may also be explained as an indication that the generative shoot production withdraws too much energy from the rhizomes, as compared to the vegetative shoot. However, very little is known about carbon transport in seagrasses (Wetzel and Penhale, 1979).

From the simulations carried out with the model at various water depths it appeared that the water mass can be subdivided into a number of vertical zones in relation to the limiting factors dominating in the particular zones: (a) From the shore down to about $1 \mathrm{~m}$ water depth, above-ground eelgrass biomass suffers from space limitation. (b) Between about 2 and $3 \mathrm{~m}$

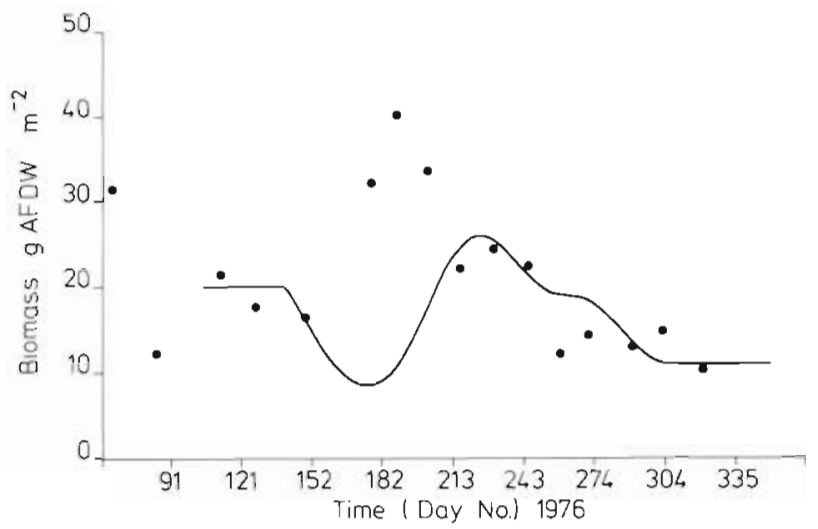

Fig. 6. Below-ground eelgrass biomass in the $10 \times 10 \mathrm{~m}^{2}$ permanent quadrat in Lake Grevelingen; water depth,

$0.75 \mathrm{~m}$. Solid line: model simulation; $\bullet$ measured data

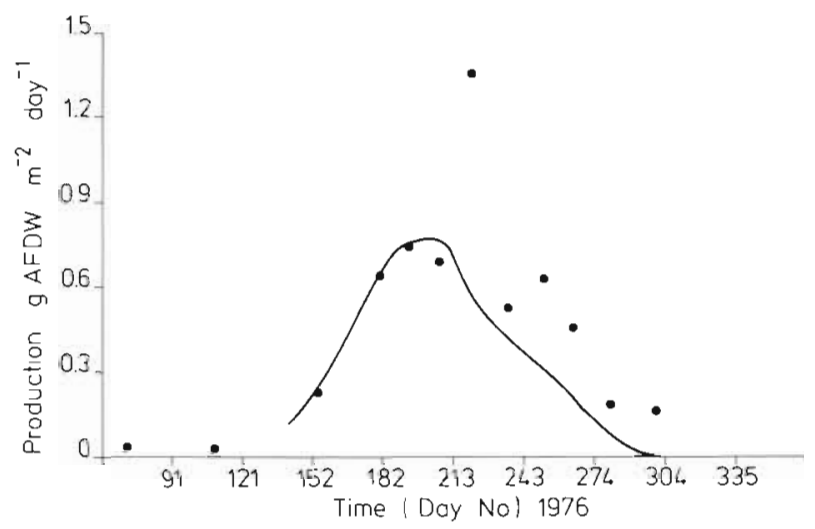

Fig. 7. Net production of below-ground eelgrass in the $10 \times 10 \mathrm{~m}^{2}$ permanent quadrat in Lake Grevelingen; water depth, $0.75 \mathrm{~m}$. Solid line: model simulation; $\bullet$ measured data

water depth, above-ground eelgrass growth is limited by the availability of below-ground biomass. (c) Between about 1 and $2 \mathrm{~m}$ water depth, both abovementioned limiting factors are effective. (d) Between 3 and $5 \mathrm{~m}$ water depth, both below-ground biomass and light act as growth-limiting factors. (e) Below $5 \mathrm{~m}$ water depth, light intensity is insufficient for sustaining net growth of eelgrass from rhizomes.

Which external factor causes the observed limitation in below-ground biomass at greater depths? This question has been studied by carrying out model simulations at different intensities of light, temperature and wind. Waves and currents cause mechanical damage to eelgrass plants and subsequent losses of leaves. In shallow water this effect is more pronounced than in deeper water, Loss of leaves, which is proportional to shoot age, is compensated for by a continuous production of new leaves rejuvenating the population. As it is assumed that below-ground production consists of a fixed percentage of the above-ground production, the below-ground biomass in shallow water is provided with more energy per unit of biomass than is the case 
in deeper water. It appeared that the production of below ground biomass, at depths below the reach of wind generated waves, is too low to cover the energy loss due to shoot production on a yearly basis.

These modelling results have been confirmed by observations (Nienhuis and De Bree, 1977, 1980): Below $2 \mathrm{~m}$ water depth, the measured below-ground biomass decreases to almost zero, whereas the aboveground biomass remains at a rather high level down to $3 \mathrm{~m}$.

Fig. 8 shows the vertical distribution of the yearly maximum of above-ground and below-ground eelgrass biomass, together with the annual production of above-ground biomass, as calculated with our model. The model results show a fairly good similarity with averaged measured data from 1974, 1975 and 1976 (Nienhuis and De Bree, 1977, 1980).

The properties of the model have been analyzed, e. $g$. its cyclic stability in a multi-year simulation. The model was stable only between about 0.5 and $2 \mathrm{~m}$ water depth. Beyond this range the eelgrass became extinct after several years. This behaviour of the model drew attention to eelgrass growing from seeds at greater depths. Unpublished 1976 data of the second author revealed that at greater water depth most shoots originates from seeds, not from rhizomes. Thus model results focussed attention to a parameter not used in the model: the role of seeds in the survival strategy of eelgrass. The presence of a fair amount of aboveground biomass and the virtual abscence of belowground biomass in water deeper than $2 \mathrm{~m}$ (Fig. 8) appears to be attributable to growth of eelgrass shoots from seeds. One of the main characteristics of the Grevelingen population is the large number of generative shoots in summer producing large amounts of seeds. Besides from perennial rhizomes, annual growth from seeds plays an important role in the maintenance and expansion of the Zostera marina population in the lake. Seeds were mainly responsible for quick colonisation of the lake following its closure in 1971 (Nienhuis, 1980). Germination of seeds and subsequent growth of shoots is also considered the main cause of differences in the year-to-year settling in deeper water.

Data on seasonal dynamics of eelgrass biomass and production have been sampled in a $10 \times 10 \mathrm{~m}^{2}$ permanent quadrat in a dense Zostera marina bed. The model describes fairly well the phenomena found in Table 5. Area covered by eelgrass $(>5 \%)$ in Lake Grevelingen

\begin{tabular}{cccc|}
\hline Year & $\mathrm{km}^{2}$ & Year & $\mathrm{km}^{2}$ \\
\hline 1968 & 12 & 1978 & 44 \\
1973 & 16 & 1980 & 26 \\
1975 & 28 & 1981 & 35 \\
\hline
\end{tabular}

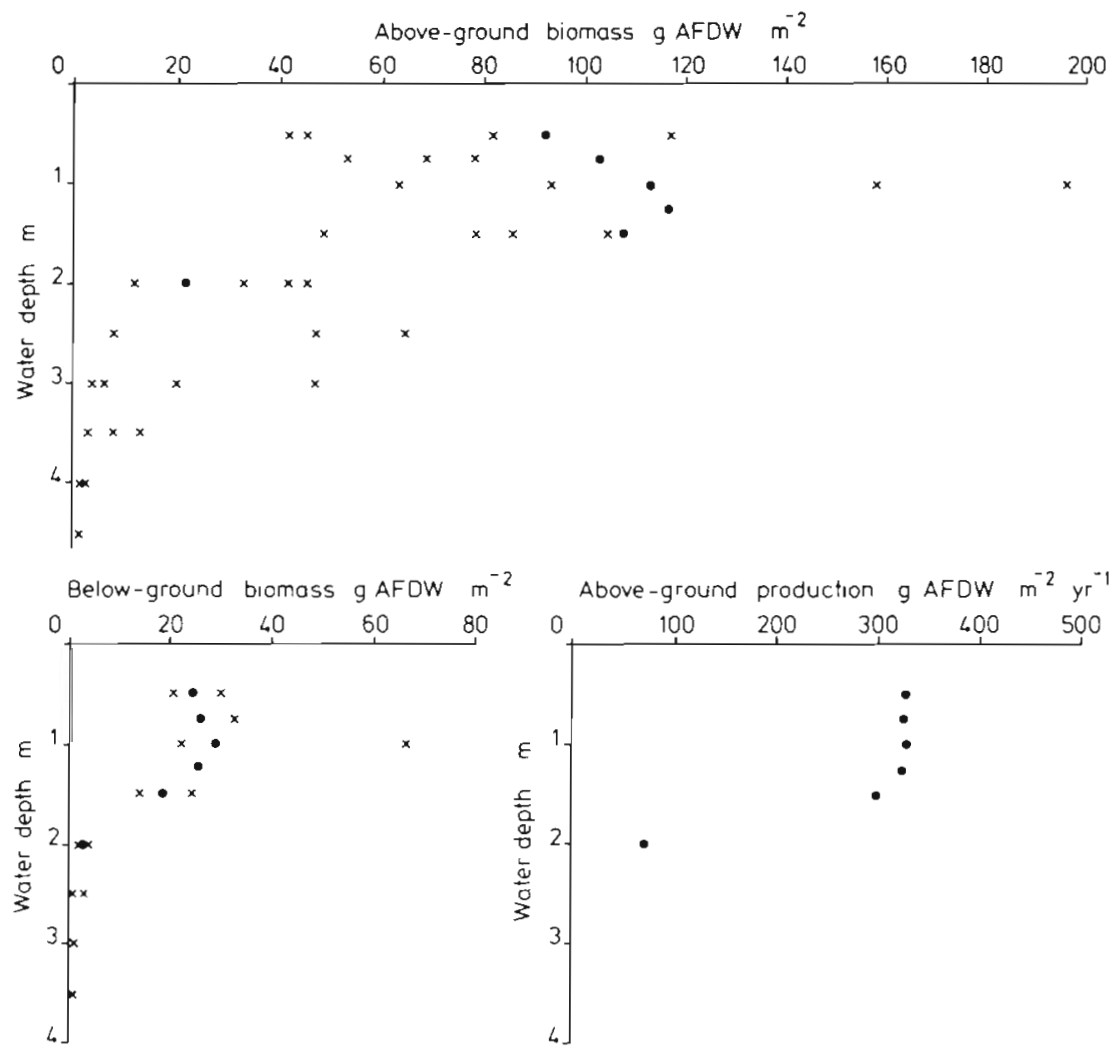

Fig. 8. Model calculations of maximum above- and below-ground biomass and of above-ground annual production of eelgrass along transects in Lake Grevelingen; various water depths. $\times$ measured data, July to August $1974,1975,1976 ; \bullet$ model simulation data 
the field for 1 year at a specific water depth. On a $\mathrm{m}^{2}$ basis, the dynamics in the chosen eelgrass stand appeared to be rather stable. As indicated by Table 5 the Grevelingen population as a whole, however, is characterized by large year-to-year fluctuations in surface area, biomass and production (Nienhuis, 1980 and in press). In addition to a number of assumed causes which are beyond the scope of this paper (Nienhuis, in press) the presence or absence of an extensive seedbank may form a powerful denominator for the dynamics observed in the eelgrass population of Lake Grevelingen.

By changing the external forcing functions in the model developed, a number of results appeared which coincide with the significance attached to seed production as evidenced in the field. Low water temperatures during the growing season, up to August, cause a reduction in biomass, in numbers of generative shoots and in concomitant numbers of seeds. This may have consequences for the distribution of eelgrass shoots in the next year. High water temperatures from August onwards to late autumn stimulate the production of vegetative shoots between August and October. It is assumed that the growth of these shoots is supported initially by translocation of organic carbon from the rhizomes. Vigorous growth of these vegetative shoots exhausts the below-ground biomass during winter. Consequently, sprouting from rhizomes during the following spring diminishes proportionally. Ultimately, this leads to a reduction in biomass and numbers of generative shoots in summer and thus to a decrease in the numbers of seeds.

The following conclusions can be drawn from this study:

(a) The simulation model - based on data of growth rates per unit eelgrass biomass, obtained with the leafmarking technique, and on biomass increase and decrease per unit area as functions of light, water temperature, water movements and ageing of eelgrass material - describes part of the seasonal changes in eelgrass production, both above and below ground.

(b) The model reveals that the vertical distribution of eelgrass can partly be explained by a combination of external and internal factors, viz. space limitation, limitation due to availability of below-ground biomass, and light limitation.

(c) Vertical and horizontal distributions of eelgrass in Lake Grevelingen, together with year-to-year variations, can only be explained by introducing a factor not used in the model, viz. seed production and growth of eelgrass shoots from seeds.

Acknowledgements. We thank the Delta Department, Environmental Research Division of the Ministry of Transport and Public Works for financial support, and Drs. E. K. Duursma, A. G. Vlasblom (DIHO, Yerseke) and H. G. Fransz (NIOZ, Texel) for critically reading our manuscript.

\section{LITERATURE CITED}

Belyeav, V I., Khailov, K. M., Okhotnikov, I. N. (1977) Mathematical simulations of a marine coastal ecosystem containing macrophytes. Aquat. Bot. 3: 315-328

Holland, A. M. B., Al, J. P. (1980). De kwaliteit van de onderwaterbodem in het Zuidelijke Deltagebied. Nota Rijkswaterstaat DDMI - 80.01: 1-39

Jansson, A. M. (1975). Systems analysis and simulation of the green algal belt (Cladophora) in the Baltic. Merentutkimuslait. Julk. Havsforskn. inst. Skr. 239: 240-247

Kelderman, P. (1981). Een interstitieel water onderzoek op vijf permanente meetplaatsen op de Grevelingenbodem in de eerste zes maanden van 1979. Delta Inst. Hydrobiol. Onderz. Rapp. Verslagen 1981-4: 1-57

McRoy, C. P. (1974). Seagrass productivity: carbon uptake experiments in eelgrass, Zostera marina. Aquacult. 4: $131-137$

McRoy, C. P. McMillan, C. (1977). Production ecology and physiology of seagrasses. In: McRoy, C. P. Helfferich, C. (eds.) Seagrass ecosystems. Dekker, New York, pp. 53-87

Nienhuis, P. H. (1980). The eelgrass (Zostera marina L.) subsystem in brackish Lake Grevelingen: production and decomposition of organic matter. Ophelia 1 (Suppl.): 113-116

Nienhuis, P. H. (in press). Wax and wane of eelgrass (Zostera marina L.) in a former estuary in The Netherlands, dominated by human activities. Mar. Technol. Soc. J

Nienhuis, P. H., De Bree, B. H. H. (1977). Production and ecology of eelgrass (Zostera marina L.) in the Grevelingen estuary, The Netherlands, before and after the closure. Hydrobiologia 52: 55-66

Nienhuis, P. H., De Bree, B. H. H. (1980). Production and growth dynamics of eelgrass (Zostera marina) in brackish Lake Grevelingen (The Netherlands). Neth. J. Sea Res. 14: 102-118

Pellikaan, G. C. (1980). De verspreiding en de groei van zeegras, Zostera marina L., in relatie tot de instraling. Delta Inst. Hydrobiol. Onderz. Studentenversl. D 8 - 1980: $1-103$

Sand-Jensen, K. (1975). Biomass, net production and growth dynamics in an eelgrass (Zostera marina L.) population in Vellerup Vig, Denmark. Ophelia 14: 185-201

Short, F. T. (1980). A simulation model of the seagrass production system. In: Phillips, R. C., McRoy, C. P. (eds.) Handbook of seagrass biology: an ecosystem perspective. Garland, New York, pp. 277-295

Verhagen, J. H. G. (1981). Een model voor de zeegrasgroei in het Grevelingenmeer. Report R1310-9. Delft Hydraulics Laboratory, pp. 1-43

Wetzel, R. G., Penhale, P. A. (1979). Transport of carbon and excretion of dissolved organic carbon by leaves and roots/ rhizomes in seagrasses and their epiphytes. Aquat. Bot. 6: $149-158$

Zieman, Y. C., Wetzel, R. G. (1980). Productivity in seagrasses: methods and rates. In: Phillips, R. C., McRoy, C. P. (eds.) Handbook of seagrass biology: an ecosystem perspective. Garland, New York, pp. 87-116 